\title{
Comparison of Mouthwash and Naso-Oropharyngeal Swab Samples in the Diagnosis of COVID-19
}

\section{COVID-19 Tanısında Gargara ve Nazo Orofarengeal Sürüntü Örneklerinin Karșılaștırılması}

Og̃uz KARABAY'(IID), Hande TOPTAN²(IiD), Elif KÖSE³(ID), Ertug̃rul GÜçLÜ1(IiD), Mehmet KÖROG̃LU²(ID)

${ }^{1}$ Department of Infectious Diseases and Clinical Microbiology, Sakarya University Faculty of Medicine, Sakarya, Turkey

${ }^{2}$ Department Medical Microbiology, Sakarya University Faculty of Medicine, Sakarya, Turkey

${ }^{3}$ Department of Public Health, Sakarya University Faculty of Medicine, Sakarya, Turkey

Cite this article as: Karabay O, Toptan H, Köse E, Güçlü E, Köroğlu M. Comparison of mouthwash and naso-oropharyngeal swab samples in the diagnosis of COVID-19. FLORA 2021;26(3):378-83.

\begin{abstract}
Introduction: In this study, we aimed to compare the place of throat mouthwash in the diagnosis of COVID-19 and the detection values of SARS-Cov-2 in naso-oropharyngeal swab (NOS) and mouthwash samples.

Materials and Methods: NOS and mouthwash water samples were taken from the patients simultaneously. Mouthwash sampling was obtained by himself. For the NOS sample; after the swab sample was taken from the patient's oropharynx with a dacron tip swab, with the same swab. RNA isolation from combined oral/nasal swab samples was performed with the EZ1 (Qiagen, Germany) device. Statistical analyses were performed using the SPSS software version 21.0.

Results: The diagnostic efficacy of throat mouthwash and combined NOS samples taken from 106 volunteers were compared (56 males, mean age 42.9 years). The diagnostic sensitivity of the mouthwash was $60.71 \%$, specificity $98.65 \%$, positive predictive value $94.44 \%$ and negative predictive value $86.9 \%$ compared to the results of the NOS. According to these results, although mouthwash is a specific test, its sensitivity to NOS is not satisfactory. The value of kappa was substantial agreement as 0.668 , and it was found statistically significant $(<0.001)$.
\end{abstract}

Conclusion: Throat mouthwash is a promising noninvasive technique for diagnosis, monitoring and infection control in patients with COVID-19 infection and reduces the risk of transmission for the healthcare provider.

Key Words: COVID-19; Diagnostic tests; SARS-CoV-2; Transmission; Viral load

${ }^{\circ}$ Copyright 2021 by Flora. Available on-line at www.floradergisi.org 


\title{
ÖZ
}

\section{COVID-19 Tanısında Gargara ve Nazo Orofarengeal Sürüntü Örneklerinin Karșılaștırılması}

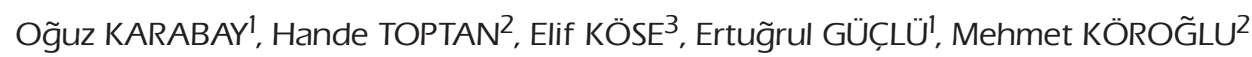

\footnotetext{
1 Sakarya Üniversitesi Tıp Fakültesi, İnfeksiyon Hastalıkları ve Klinik Mikrobiyoloji Anabilim Dalı, Sakarya, Türkiye

2 Sakarya Üniversitesi Tıp Fakültesi, Tıbbi Mikrobiyoloji Anabilim Dalı, Sakarya, Türkiye

${ }^{3}$ Sakarya Üniversitesi Tıp Fakültesi, Halk Sag̃lıg̃ı Anabilim Dalı, Sakarya, Türkiye
}

Giriş: Bu çalışmada boğaz gargarasının COVID-19 tanısındaki yerini, Nazo-orofaringeal sürüntü (NOS) ve gargara suyu örneklerinde SARS-Cov-2'yi saptama değerlerini karşılaştırılmayı amaçladık.

Materyal ve Metod: Hastalardan eş zamanlı olarak nazo-orofaringeal sürüntü (NOS) ve gargara suyu (hastanın kendisi tarafından) örnekleri alındı. NOS örneği için; hastanın orofarenksinden dakron uçlu swab ile sürüntü örneği alındıktan sonra, aynı sürüntü çubuğu ile burundan da örnek alındı. Sürüntü örneklerinden RNA izolasyonu EZ1 (Qiagen, Almanya) cihazı ile yapıldı. ístatistiksel analizler SPSS yazıımının 21.0 versiyonu kullanılarak yapıldı.

Bulgular: 106 gönüllüden alınan boğaz gargarası ve kombine NOS örneklerinin tanısal etkinliği karşılaştırıldı (56 erkek, ortalama yaş 42.9 yıl). Ağız gargarasının tanısal duyarlıı̆ı NOS sonuçlarına göre \%60.71, özgüllük \%98.65, pozitif prediktif değer \%94.44 ve negatif prediktif değer \%86.9 idi. Bu sonuçlara göre gargara spesifik bir test olmasına rağmen NOS'a duyarlılığı tatmin edici değildir. Kappa değeri 0.668 olarak önemli bir uyum ve istatistiksel olarak anlamlı bulunmuştur $(<0.001)$.

Sonuç: Boğaz ve ağız gargarası, COVID-19 infeksiyonu olan hastalarda teşhis, izleme ve infeksiyon kontrolü için ümit verici, invazif olmayan bir tekniktir ve sağlık hizmeti sağlayıcısı için bulaşma riskini azaltır.

Anahtar Kelimeler: COVID-19; Tanı testleri; SARS-CoV-2; Transmisyon; Viral yük

\section{INTRODUCTION}

The COVID-19 infection epidemic that started in China at the end of 2019 has affected hundreds of thousands of people and caused a worldwide pandemic. The infection spread by this epidemic caused thousands of deaths. The most common diagnostic method used in the $\mathrm{COV}$ ID-19 outbreak is the detection of viral nucleic acid isolated from the patient's nasopharyngeal and oropharyngeal swab (NOS) sample by polymerase chain reaction $(\mathrm{PCR})^{[1]}$. However, during the sampling process, aerosols can be generated and healthcare personnel in close contact with the patient are at serious risk for COVID-19 infection. In addition, NOS causes discomforts (nausea, nosebleeds) in patients. Therefore, there is a need for different samples and sampling methods that pose less risk to healthcare professionals.

A throat gargle is easier for patients to take by themselves and the need for medical staff is less. Based on the literature, we thought that if a throat mouthwash is used instead of the throat and nasal swab samples, the patient will be satis- fied with this situation and health personnel may not be exposed to the risk of transmission ${ }^{[2]}$. For this purpose, we aimed to investigate the sensitivity, specificity, and positive and negative predictive values of throat mouthwash samples by accepting PCR results in NOS as the gold standard from the pre-diagnosed patients with COVID-19 infection.

\section{MATERIALS and METHODS}

This research was conducted between March 13 and April 2, 2020, when the COVID-19 epidemic occurred throughout the world. Volunteers who applied to the Sakarya University Training and Research Hospital and who were evaluated within the scope of the COVID-19 possible case definition published in the national guidelines and who had evidence of infection were included in the study.

Combined NOS and mouthwash water samples were taken from the patients simultaneously. Before the study, all volunteers were informed about the study, and ethical consent was obtained from the ethics committee of Sakarya University Medical Faculty for the study. 


\section{Nasopharyngeal and Oropharyngeal Swab Sampling}

The sampling process was considered as a process that could cause droplet/aerosolization, and a healthcare provider wore personal protective equipment (at least N95/FFP2 mask, goggles, or face protection) and carried out sampling ${ }^{[2]}$.

For the NOS sample; after the swab sample was taken from the patient's oropharynx with a dacron tip swab, NOS (sampling with a rotating motion from middle nasal concha and nasopharynx) was also performed with the same swab and the swab was placed into $5 \mathrm{ml}$ tubes containing $2 \mathrm{ml}$ viral transport medium. The outer part of the swab was cut and the cap of the tubes was closed.

\section{Preparation of Mouthwash Water/ Throat Gargle Solution and Sampling and Transportation}

Quantities of $0.061 \mathrm{M}$ disodium monohydrogen phosphate heptahydrate $\left(\mathrm{Na}_{2} \mathrm{HPO}_{4} * 7 \mathrm{H}_{2} \mathrm{O}\right)$ and $0.039 \mathrm{M}$ monosodium dihydrogen phosphate dihydrate $\left(\mathrm{NaH}_{2} \mathrm{PO}_{4} * 2 \mathrm{H}_{2} \mathrm{O}\right)$ were calculated for $500 \mathrm{~mL}$ buffer solution. With $0.1 \mathrm{~N} \mathrm{H}_{3} \mathrm{PO}_{4}$ and $0.1 \mathrm{M} \mathrm{NaOH} ; \mathrm{pH}$ was set to 7.2-7.4. Then sucrose was added with a final concentration of $5 \%$. Thus, an environment similar to a viral transport medium was created. Prepared mouthwash solutions were dispensed $5 \mathrm{ml}$ each in a sterile sealed container.

Mouthwash sampling was described to the patient by the healthcare provider. The patient himself/herself gave the sample in a separate room. Patients were asked to gargle the sterile solution with the head in full flexion position in the mouth for at least 5 seconds, put the liquid back to the same sample container $(100 \mathrm{ml}$ screw cap sealed container), close the lid and deliver it to the staff. The staff received the container with gloves, then, after performing the external cleaning of the container with $1 / 10$ diluted bleach-impregnated cloth, s/he delivered both samples to the sample acceptance table set up for COVID-I9. After taking both samples, they were kept in the refrigerator at $2-8^{\circ} \mathrm{C}$ and immediately delivered to the laboratory. The samples were sent to the laboratory under cold chain rules with the triple transport system, following infection prevention and control procedures.

\section{Nucleic Acid Isolation and RT-PCR (Real Time-Polymerase Chain Reaction) Study}

After the acceptance of the samples in the microbiology laboratory, the samples were taken to the level 3 biosafety negative pressure room, and the combined NOS samples and mouthwash water were lined up one after another respectively.

RNA isolation from combined oral/nasal swab samples was performed with the EZ1 (Qiagen, Germany) device. Elution of $60 \mu \mathrm{L}$ of $400 \mu \mathrm{L}$ sample was taken and used as a template in RT-PCR reaction.

For RNA isolation from mouthwash water samples, the samples were first mixed with 300 $\mu \mathrm{L}$ Type 1 water in $1 / 1$ ratio. $400 \mu \mathrm{L}$ of this mixture was taken into the sampling tube on the EZ1 device and the remainder of the isolation was carried out in line with the company's recommendations.

For the study, $10 \mu \mathrm{L}$ master mix, $2 \mu \mathrm{L}$ primer, $8 \mu \mathrm{L}$ RNA mixture were prepared per sample with genesis Real-Time PCR COVID-19 (Primer Design, UK) kit. Orf1ab gene region was used in the primary design kit. The reaction was carried out at the following time and temperature with a total reaction volume of $20 \mu \mathrm{L}$.

At the end of the reaction, Cycle Threshold (CT) values were used as an approximate indicator of the number of copies of the COVID-19 RNA. A CT value of less than 45 was interpreted as positive for the COVID-19 RNA. Real-time PCR steps are shown in Table 1.

\section{Data analysis}

Statistical analyses were performed using the SPSS software version 21.0. The variables were investigated using visual(histogram) analytic methods (Kolmogorov-Smirnov/ Shapiro Wilk's test) to determine whether or not they are normally distributed. Descriptive analyses were presented using medians and quartiles for the non-normally distributed variables. The cycle numbers of the PCR assay according to sampling methods were compared using the Wilcoxon test since they did not show normal distribution. 
Table 1. Time and temperature values of COVID-19 real-time PCR assay

\begin{tabular}{|c|c|c|c|}
\hline \multicolumn{2}{|l|}{ Cycles } & Temperature & Time \\
\hline \multicolumn{2}{|c|}{ Reverse transcription } & $55^{\circ} \mathrm{C}$ & 10 minute \\
\hline \multicolumn{2}{|c|}{ Enzyme activation } & $95^{\circ} \mathrm{C}$ & 2 minute \\
\hline \multirow[t]{2}{*}{ X50 cycles } & Denaturation & $95^{\circ} \mathrm{C}$ & 10 second \\
\hline & Annealing and extension & $60^{\circ} \mathrm{C}$ & 60 second \\
\hline
\end{tabular}

The agreement between the two sampling methods was evaluated with the kappa test. Kappa is a measure of this difference, standardized to lie on a -1 to 1 scale, where 1 is a perfect agreement, 0 is exactly what would be expected by chance $(<0$ Less than chance agreement, 0.01-0.20 Slight agreement, 0.21-0.40 Fair agreement, 0.41-0.60 Moderate agreement, 0.61-0.80 Substantial agreement, 0.81-0.99 Almost perfect agreement) ${ }^{[3]}$. A p-value of less than 0.05 was considered to show a statistically significant result.

\section{RESULTS}

In this study, samples were taken from 106 volunteers (56 males and 50 females). The mean age was 42.9 years. The value of kappa was substantial agreement as 0.668 , and it was found statistically significant $(<0.001)$. Sensitivity, specificity, positive predictive value, negative predictive values are presented in Table 2 , and mean PCR cycles are presented in Table 3.

Table 2. Statistical analysis results of the mouthwash sampling method

\begin{tabular}{lc} 
Properties & Mouthwash sample (\%) \\
\hline Sensitivity & 60.71 \\
Specificity & 98.65 \\
PPV* & 94.44 \\
NPV** & 86.90
\end{tabular}

*PPV: Positive predictive value.

${ }^{* *} \mathrm{NPV}$ : Negative predictive value.

\section{DISCUSSION}

Bronchoalveolar lavage fluid (BALF) is the best sample in the evaluation of the presence of the viral RNA in COVID-19 suspected patient. However, it is not easy to apply this procedure in high-risk diseases. Therefore, in the diagnosis of COVID-19 infection; gargle, nasopharyngeal swab, sputum, blood, and stool samples are also used. Nowadays, nasopharyngeal swabs and sputum are frequently preferred ${ }^{[4]}$. In the outbreak of COVID-19, one of the most commonly used tests to diagnose this infection is the PCR test. However, coronavirus is easily transmitted by respiratory secretions. Therefore, healthcare personal can easily become infected while swabbing the respiratory tract from patients.

The classic nasopharyngeal swab is taken from the patient's throat and nose, and it is essential to have experienced staff while doing this operation. However, here we recommend the mouthwash method when a short description is made to the patient, the patient can take a sample by him/herself, and enables the healthcare staff to provide a diagnostic sample without risking COVID-19 transmission. Also, a sample taken with a dacron-tipped swab is required when taking a throat sample. Cotton or calcium alginate swabs are not suitable for molecular virus studies. This special swab requirement can also lead to difficulty in obtaining through outbreak times. However, mouthwash sampling does not require any extra equipment and can be taken

Table 3. Cycle threshold (CT) values of positive resulted samples by two sampling methods

\begin{tabular}{lcccccc} 
Method & Mean & Standard Deviation & Median & 1.-3. quartiles & Min-max & $\mathbf{p}^{*}$ \\
\hline CT of Oral/nasal swab samples & 31.02 & 5.95 & 29.93 & $26.43-33.27$ & $23.04-44.50$ & 0.586 \\
CT of Mouthwash samples & 31.27 & 7.62 & 30.12 & $25.53-34.01$ & $20.45-46.00$ & \\
\hline
\end{tabular}

*Wilcoxon test applied. 
with a homogeneous distribution around the throat. Besides, the patient's ability to take on his own provides a great advantage.

Mouthwash samples can be easily taken from patients into a sterile container. Since invasive procedures are not required, collecting the mouthwash sample can greatly minimize the chance of exposing healthcare providers to COVID-19. However, the sensitivity and specificity of mouthwash samples compared to nasopharyngeal samples in the detection of respiratory viruses including coronaviruses were found to be $60.1 \%$ and $98.7 \%$, respectively. The fact that the specificity of the mouthwash sample is so good gives quite reassuring results for negative samples. However, we think that the results in sensitivity are not satisfactory. This may be related to the dilution of viral nucleic acid in mouthwash. To test this situation, this research can be repeated with less amount of mouthwash. Another reason for the low sensitivity is that the NOS sampling was made from both the nasopharynx and the throat with the same swab ${ }^{[4,5]}$. However, the mouthwash sample was taken only from the throat. Another reason for low sensitivity in the mouthwash may be related to the fact that the viral load in the mouth is not as high as in the nose. Zou et al. have shown in their study with 72 respiratory samples obtained from 14 patients that viral density in nasal samples was higher than throat samples ${ }^{[5]}$. In this study, the low susceptibility rate we detected in mouthwash may be related to virus density in the throat. Whereas, in combined nasal/oral sampling, swabs from both regions may have caused a higher sensitivity than the throat gargle taken alone. Wang et al. $^{[5,6]}$, in their study with patients diagnosed with COVID-19 based on symptoms and radiology, and confirmed with the detection of COVID-19, took different sample types from patients and the COVID-19 positivity rate in respiratory tract samples was 93\% in bronchoalveolar lavage, 72\% in sputum, $62 \%$ in the nasal swab, and $32 \%$ in the pharyngeal swab. It is noteworthy that the nasal swab was able to detect only $1 / 3$ of the cases. Pharyngeal swabs were able to detect only $1 / 3$ of the cases. In this study, while swab samples were taken with both nasopharyngeal and oropharyngeal sampling, gargle was taken only with oropharyngeal sampling.

There are studies in the literature on gargle lavage as a suitable alternative to sampling collection swabs for the detection of SARSCoV-2 ${ }^{[7,8]}$. It can be considered as a suitable alternative in terms of its ability to provide selfsampling, relieve the burden of healthcare workers and reduce the need for personal protective equipment, resulting in significant cost savings. The fact that the specificity and sensitivity of gargle lavage were not calculated in the previous studies reveals the importance of this study.

A limited number of studies have been reached in the literature on the detection of COVID-19 RNA in mouthwash, and SARS-CoV RNA was investigated in samples of SARS patients in China during the SARS period in 2004. The positive rates of urine, stool, and mouthwash were $14.7 \%$ (26/177), 11.9\% (21/177), and 13.6\% (24/177), respectively. The low positivity rates may be due to patients being in the convalescent phase ${ }^{[9]}$.

The specificity, positive predictive, and negative predictive value of this test are quite satisfactory. In a recent study, COVID-19 has been searched for only 12 patients' saliva, and very high rates have been reported. In that study, 11/12 patients have isolated the virus in their saliva. However, these data obtained with a low number of patients should be carefully evaluated ${ }^{[10]}$.

Before conclusion, we should declare limitation of our study. The fact that the study was conducted with a limited number of people due to the budget of the project is a limitation.

\section{CONCLUSION}

The most important advantage of the mouthwash method is that the patient can take a sample without risking the healthcare workers, does not cause nausea in the patient, and is not invasive. The kappa value of the mouthwash method is satisfactory compared to the NOS. However, the low sensitivity of the method should be considered. Although there is no difference between naso-oropharyngeal swab and the throat mouthwash in terms of effectiveness, the sample taken with the mouthwash is more reliable and less risky. 


\section{ACKNOWLEDGEMENT}

We thanked to Sakarya University Science, Research and Project Department for the support our study (Project Number: 2020-6-23-84).

\section{ETHICS COMMITTEE APPROVAL}

This study was obtained from Sakarya University Non-invasive Studies Ethical Committee (Date: 04.04.2020, Decision No: 111).

\section{CONFLICT of INTEREST}

None of the authors had conflict of interest.

\section{AUTHORSHIP CONTRIBUTIONS}

Concept and Design: OK, EG, EK

Data Collection or Processing: OK, EK

Analysis/Interpretation: MK, HT

Literature Search: EK, OK

Writing: OK, EK

Final Approval: All of authors

\section{REFERENCES}

1. Chan JF-W, Yuan S, Kok K-H, To KK-W, Chu H, Yang J, et al.A familial cluster of pneumonia associated with the 2019 novel coronavirus indicating person-to-person transmission: a study of a family cluster. Lancet 2020;395:514-23.

2. Malecki M, Lüsebrink J, Teves S, Wendel AF, Pharynx gargle samples are suitable for SARS-CoV-2 diagnostic use and save personal protective equipment and swabs, Infect Control Hosp Epidemiol 2021 Feb;42(2):248-9.

3. Viera AJ, Garrett JM. Understanding interobserver agreement: the kappa statistic. Fam. Med 2005;37:360-3.
4. Chen E-Q, Wang L-C, Tang G-M, Yang Y, Wang M-J, Deng $R$, et al. Brief report of the first cured 2019-nCoV pneumonia patient in West China Hospital. Eur I Clin Microbiol Infect Dis Accessed on 27 March 2020.

5. Zou L, Ruan F, Huang M, Liang L, Huang H, Hong Z, et al. SARS-CoV-2 Viral Load in Upper Respiratory Specimens of Infected Patients. N. Engl. J. Med 2020;19; 382:1177-9.

6. Wang W, Xu Y, Gao R, Lu R, Han K, Wu G, Tan W. Detection of SARS-CoV-2 in Different Types of Clinical Specimens. JAMA Accessed on 11 March 2020.

7. Mittal A, Gupta A, Kumar S, Surjit M, Singh B, Soneja M, et al. Gargle lavage as a viable alternative to swab for detection of SARS-CoV-2. Indian J Med Res 2020 Jul-Aug;152(12):77-81.

8. Saito $M$, Adachi E, Yamayoshi S, Koga M, Iwatsuki-Horimoto $K$, Kawaoka $Y$, Yotsuyanagi $H$. Gargle Lavage as a safe and sensitive alternative to swab samples to diagnose COVID-19: A Case Report in Japan. Case Reports Clin Infect Dis 2020 Jul 28;71(15):893-4.

9. Ren $Y$, Ding $H G, W u Q F$, Chen $W J$, Chen $D, B a o Z Y$, et al. Zhongguo Yi Xue Ke Xue Yuan Xue Bao. [Quantitative detection of SARS-COV RNA in excreta and oropharyngeal washing fluid from convalescence patients with severe acute respiratory syndrome] 2020;26:251-4.

10. To KK-W, Tsang OT-Y, Chik-Yan Yip C, Chan K-H, Wu T-C, Chan JMC, et al. Consistent detection of 2019 novel coronavirus in saliva. Clin Infect Dis. Accessed on 12 March 2020.

\section{Address for Correspondence/Yazıșma Adresi}

Dr. Elif KÖSE

Sakarya Üniversitesi Tıp Fakültesi,

Halk Sağlığı Anabilim Dalı

Sakarya-Türkiye

E-posta: elifkose@sakarya.edu.tr 